\title{
The Impact of Strategic Planning in Palestinian Municipalities on the Quality of Service Provided to Its Citizens
}

\author{
Asma' Omar Dris Kharroub ${ }^{1}, \&$ Majeed Mustafa cOthmanMansour ${ }^{2}$ \\ ${ }^{1}$ General Director of Gender Unit, Ministry of Local Government, Palestine \\ ${ }^{2}$ Associate Professor, Marketing, Arab American University, Palestine \\ Correspondence: Majeed Mustafa cOthmanMansour, Associate Professor, Marketing, Arab American University, \\ Palestine.
}

Received: March 4, 2019

Accepted: April 2, 2019

Online Published: April 17, 2019

doi:10.5539/ibr.v12n5p69

URL: https://doi.org/10.5539/ibr.v12n5p69

\begin{abstract}
The purpose of this study is to investigate the impact of strategic planning in Palestinian Municipalities on the Quality of service provided to citizens. Secondary data were obtained by reviewing journals, books, bulletins, textbooks, scientific articles, newspapers, periodicals etc. Primary data was collected by a specific questionnaire. The questionnaire consisted of (45) items divided into three main sections: personal information, the strategic planning, and the dimensions of the quality. A random sample of One hundred and twenty (120) questionnaires were distributed to the employees of Jenin Municipality, one hundred and fourteen (114) questionnaires were retrieved and 6 cases were (missing cases). The researcher adopted SERVQUAL model in this study and made some adaptation on it to match the main objectives of the study. In order to answer the study question the researcher followed the analytical descriptive approach and tested three main hypotheses which were clarified in the study. The Main findings showed that strategic planning has a positive correlation and impact on the quality of the service provided to citizens, as well as the sub-hypothesis, (tangibility, reliability, responsiveness, empathy, and assurance) examined by the view of respondents and this applies to all the four factors (vision, mission, objectives, and the strategic choices), the level of satisfaction of the quality of the service provided by Jenin municipality which was measured by the employees was moderate. The researcher recommended the Palestinian Municipalities to promote quality culture and encourage employees to participate in continuous improvement processes and opportunities for creativity and innovation.
\end{abstract}

Keywords: strategy, strategic management, strategic planning, quality, service quality, SERVQUAL, jenin municipality

\section{Background of the Study}

Strategic management is one of the most basic tools available for managers for the construction of a systematic administrative system (Bērziffs, 2015). Strategic planning is defined as "an ongoing, systematic process that takes a forward-looking approach to an organization's goals and objectives" (Di Napoli, 2003, P. 40).

Planning experience in Palestine is distinguished by progressive development, since the advent of the Palestinian National Authority to the homeland in 1994 planning took local practicality gradually began in preparing Emergency Qualification Program (ERP) in collaboration with the World Bank, this was followed by setting the Palestinian investment program for two years (1996-1997), then moved to short-term programs and medium-term plans (Ministry of Planning and International Cooperation, Emergency and Investment Plan 2003-2004). Palestinian municipalities have adopted the strategic developmental planning in tune with the policy of the Ministry of Local Government, which was contained in its strategic plans for the institutionalization of the municipal and village councils work, then specialized committees were formed for drafting and developing these plans (Al-Qeeq, 2015).

The purpose of strategic planning for any organization is to identify where the organization is now and where it is going and how to reach there, Strategic planning is not only an important basis for the work implementation of the organization, but it is also putting the organization structure and improves its performance in risk management and portfolio management for any initiatives at the enterprise level (Mellon, 2010).

Strategic development plan is considered a major component and a key requirement in the development of 
municipalities and communities that seek to progress, promotion and advancement of its internal status and the services provided to citizens (Al-Qeeq, 2015). The total quality theories involved in considering strategic planning as an indicator to reach the total quality through mastering work and improve services in all fields (Alshikh, 2014).

Efficient services are recognized when the service provider respond to customer request and when all citizens have access to the services provided and when the administration work to ensure that the services match with the request for all consumers (Webster et al, 2011). When quality is available satisfied customers will increase in number, buy more, pay their bills promptly which improves cash flow and the livelihood of the organization (Nashappi et al, 2014).

Quality theories have developed toward strategic planning consideration as one of the indicators that access to quality requires mastery of work and improve services in all aspects begins with strategic planning and ends with an assessment (Al-Shikh. 2014).

\subsection{Problem Statement}

To provide the value of customers became one of the most important strategies, and customers are now considered as the most important assets. The lack of successful implementation remains alarming given the significance of the customer to the service operations and strategy (Nashappi et al, 2011).

Strategic planning is assumed to produce the response to citizens' needs and provide services with good quality which satisfy all citizens levels, this study focuses on answering the following main question: what is the impact of adopting strategic planning in Jenin municipality on the quality of service provided to citizens in Jenin city?

\subsection{Study Questions}

The main question of this study is: what is the impact of adopting strategic planning in Jenin municipality on the quality of service provided to citizens in Jenin city?

\subsection{Sub. Questions}

1- What is the degree of the available strategic planning in Jenin municipality?

2-What is the level of the quality of service provided to citizens in Jenin municipality?

3- Is there a relationship between the strategic planning factors (vision, mission, objectives, strategic choices) and the quality of service dimensions (tangibility, reliability, responsiveness, security, assurance) in Jenin municipality?

4- What is the impact of strategic planning factors (vision, mission, objectives, strategic choices) on the quality of service dimensions (tangibility, reliability, responsiveness, security, assurance) in Jenin municipality?

\subsection{Study Objectives}

The main Objective of this descriptive analytical study is to realize if there is an impact of the strategic planning in Jenin Municipality on the quality of service provided to the citizens in Jenin city.

1- To identify the level of the available strategic planning in Jenin municipality;

2- To know the level of the quality of service in Jenin municipality;

3- To recognize the relationship between the strategic planning factors (vision, mission, objectives, strategic choices) and the quality of service dimensions (tangibility, reliability, responsiveness, security, assurance) in Jenin municipality;

4- To identify the impact of strategic planning factors (vision, mission, objectives, strategic choices) on the quality of service dimensions (tangibility, reliability, responsiveness, security, assurance) in Jenin municipality;

\subsection{Significance of the Study}

According to the literature review that the researcher studied, she supposes that this is the first study in Palestine which measure the impact of strategic planning on the quality of service provided to citizens by Jenin municipality. Through this study, the researcher sought to:

1- Add the value of adopting the strategic planning in the Palestinian municipalities and associating the strategic planning with the quality of service provided to citizens by municipalities;

2- This study will add value to the performance of municipalities which is considered by customers when implementing quality in their service to achieve customers' satisfaction;

3- The scientific significance of answering the research question which is the core of this study; 
4- Recognize the impact of strategic planning on the quality of service provided to citizens in Jenin city;

5- The researcher suggested some recommendations to link strategic planning with the quality of service in Jenin municipality and other Palestinian municipalities to improve the quality of service in the Palestinian municipalities.

\subsection{Study Hypotheses}

In order to answer the study question: what is the impact of adopting strategic planning in Jenin municipality on the quality of service provided to citizens in Jenin city? the researcher developed four main Hypotheses as follows:

H0.1: There is no significant relationship between the strategic planning factors (vision, mission, objectives, strategic choices) and the quality of service dimensions (tangibility, reliability, responsiveness, security, assurance) in Jenin municipality at the level $\alpha \leq 0.05$.

H0.2: There is no significant impact at $(\alpha \leq 0.05$.) of strategic planning factors (vision, mission, objectives, strategic choices) on the quality of service in Jenin municipality

\subsection{Study limitations}

1. Objective limits: This study was limited to examining the impact of strategic planning on the quality of service provided to citizens by Jenin municipality;

2. Spatial boundaries: Jenin municipality, the sample was taken from Jenin municipality employees;

3. Time limits: The study covers the period from March 2017 to January 2018.

\section{Theoretical Framework}

Modern administrations face increasing challenges as a result of the acceleration of changes and developments in the late twentieth century. The response to these changes and developments is reflected in the ability of the administration to play its role in business organizations as a means of the organization at all levels and forms to utilize and invest its resources to achieve its objectives. The success or failure of the organization depends on its ability to achieve its mission, goals, and objectives, which requires the development of a strategy for the organization and the pursuit of implementation in light of the various changes surrounding the organization (Al-Sakarnah, 2015, p. 23). The twenty-first century has witnessed the appearance and growing acceptance of new trends of research that offer more supportive means of overcoming organizational realities (Johnson et al. 2008.P. 17). Strategic planning is considered the only way for the organization to follow up the implementation or modification of its strategy. However, the strategic planning so far has not received enough attention and is not applied in most of the products or service sectors, and the tools used to measure the performance so far limited to the traditional tools which assess the financial aspect and neglect other important aspects of customer satisfaction and quality measurement (Al-Sakarnah, 2015, p. 23).

\subsection{Strategy}

Strategy is a word that has many meanings relevant and useful to those who are interested in developing a strategy for business organizations, profit organizations and nonprofit organizations. Alfred D. Chandler, Jr., (1962) in his book Strategy and Structure, defined strategy as "the determination of the basic long-term goals and objectives of an enterprise, and the adoption of courses of action and the allocation of resources for carrying out these goals." In (1994) Henry Mintzberg determined that strategy is a plan, a pattern, a position, a perspective, and in the margin, it can also be a trick, a maneuver aimed at competing. Fred Nickols in (2016) when he was head of Strategic Planning and Management Services at Educational Testing Service proposed a definition of a strategy: "Strategy refers to a general plan of action for achieving one's goals and objectives" (Nickols, 2016, pp.1-3). Strategy is "the direction and scope of an organization over the long term, which achieves advantage in a changing environment through its configuration of resources and competences with the aim of fulfilling stakeholder expectations". Finally, the strategy of an organization organizes a comprehensive major plan that states how the organization will attain its mission and objectives (Wheelen and Hunger, 2012, p. 43).

\subsection{Strategic Planning}

Planning is management role which involves in putting objectives and defining a path of work to obtain those objectives. In planning, managers must be aware of environmental situations facing their organization and estimate of future circumstances. Managers also must be good decision makers. (Carpenter et al. 2012, p.p. 22-28). According to the business dictionary, strategic planning is defined as a "systematic process of 
envisioning a desired future and translating this vision into broadly defined goals or objectives and a sequence of steps to achieve them". Strategic planning is the optimize use of resources, invest in opportunities and overcome weaknesses to reduce external threats and competitors. Strategic planning as a concept is defined: " a long-term planning that takes into account internal and external variables identifies the sectors and target market segments and the method of competition and is a renewable process that is updated every year to study internal and external developments" (Al-Sakarnah, 2015, P. 32). Strategic planning "The process of analyzing competitive opportunities and threats, as well as the strengths and weaknesses of the organization, and then determining how to position the organization to compete effectively in its environment" (Carpenter et al. 2012, P. 28). Strategic planning is a systematic process to indicate and achieve tasks that take advantage of the strengths and weaknesses of the municipality while recognizing there are threats and external opportunities that have an impact on the municipality. It is the cornerstone of achievement the purpose of any municipality plan. It provides the municipality a means to design its desired future rather than responding to events as unfolding. It provides the municipality with an opportunity to develop a vision of its required future with the collaboration of all stakeholders. The process also includes steps to ensure that the current strategic plan continues and responds to and adapts to the changing surroundings. (Di Napoli, 2003, P. 1-2).

The purpose of strategic planning for any organization is to identify where the organization is now and where it is going and how to reach there, Strategic planning is not only an important basis for the work implementation of the enterprise, but it is also putting the organization structure and improves its performance in risk management and portfolio management for any initiatives at the enterprise level (Mellon, 2010).

Strategic planning is a process and technique to the service of the public sector. By applying strategic planning in their job, public organizations can make appropriate decisions to manage restricted resources in a logical way, towards increasing and improving services and obtaining a major gratification of citizens (Salkić, 2014, P. 62).

Through the last two decades, there has been a broad kind of new management methods, such as cost-benefit analysis, planning-programming-budgeting systems, management by objectives, total quality management, etc. However, strategic planning has increased in popularity and use as an effectual management tool, mostly with municipalities. Strategic planning is a systematic method of controlling change and enhancing a better future in the light of changes. It is an innovative operation for identifying and achieving plans that take the benefits of the municipality's strengths, weaknesses, threats, and opportunities. It can also give the society a clearer image of the municipality's special identity and care about the aspects that the municipality failed to notice before (Service Nova Scotia and Municipal Relations, 2000, pp. 5-6). There are five main benefits for the municipality to accomplish a strategic plan (Service Nova Scotia and Municipal Relations, 2000, pp. 5-6):

1. The key benefit of strategic planning is encouraging strategic thinking and attitude;

2. Strategic planning can help the municipality formulate and lead its strategic intents clearly. It can help in making today's decisions in the light of future conclusions;

3. Strategic planning can strengthen the municipality's organizational response and execution, where the municipality is motivated to illustrate and classify key organizational matters and comply wisely to requirements and internal and external constraints.

4. Strategic planning can promptly support policy makers and decision makers in improving their performance of their roles and implement their duties. It is likely that teamwork and experience will be strengthened among all municipal staff;

5. A strategic plan supplies the preliminary work for a municipality to perform an inclusive action plan.

Strategic development plan is considered a major component and a key requirement in the development of municipalities and communities that seek to progress, promotion and advancement of its internal status and the services provided to citizens (Al-Qeeq, 2015). The total quality theories involved in considering strategic planning as an indicator to reach the total quality through mastering work and improve services in all fields (Al shikh, 2014).

The researcher defines strategic planning as a systematic process by the organization which defines the organization vision, mission and strategic objectives then choose the best available strategic choices to achieve the desired goals. From the previous definition, four components of strategic planning will be adopted in this study: vision; mission; objectives; and strategic choices.

Vision or strategic intent is "the desired future state of the organization". It is "an aspiration around which a strategist, perhaps a chief executive, might seek to focus the attention and energies of members of the organization"(Johnson et al. 2008, p.10). The vision statement is what the Organization aspires to. Its purpose is 
to develop a view of the future in order to promote, get committed and extend performance (Johnson et al. 2008, pp.163-164).

Mission: An organization's mission is the purpose or reason for the organization's existence. It tells what the company is providing to society- either a service or a product (Wheelen and Hunger, 2012, p. 41). It is a general term for the overall purpose of the organization, which, ideally, is in line with the values and expectations of key stakeholders and concerned with the scope and boundaries of the organization. Sometimes it is indicated to in terms of the apparently simple but challenging question: 'What business are we in?' (Johnson et al. 2008, p.10). The aim of the mission statement is to supply employees and stakeholders with a clear visibility about the general purpose of the corporation and the reason for its existence. It is, therefore, to do with building understanding and trust about how the strategy of the corporation connect with that purpose (Johnson et al. 2008, pp.163-164). A mission statement and a vision statement are typically concerned with the purpose of an organization in terms of its strategic direction. The strategic mission declares management customized answer to the question" what our business is and what will it be?" A mission statement in general outlines the organization's future trend and serves as an acquiring concept for what the organization is to do and to become. What is our business? (Nábrádi, 2006, p. 29). In practice, the distinction between mission and vision statements can be hazy but they are intended to be different as follows: When the organization uses the word goal in its strategy, the goal generally means a common objective with the mission line. It might be qualitative in nature. While, an objective is further probably to be quantified, or at least to be a more accurate target in line with the goal (Johnson et al. 2008, p.10).

Objectives are "statements of specific outcomes that are to be achieved" (Johnson et al. 2008, P. 164). Objectives are the end results of planned activity. They tell what is to be accomplished by when and quantified if possible. The achievement of corporate objectives should result in the fulfillment of a corporation mission (Wheelen and Hunger, 2012, p. 42). At the corporate and business unit levels objectives are often expressed financially. This can be an expression of desired sales or earnings levels, growth rates, dividend levels or stock assessment (Hutton, 2001, cited in Johnson, et al. 2008). However, the corporations may also have market-based objectives, many of which are quantified as objects - such as market share, customer interest, business replication, etc. When determining goals, managers should consider three related issues (Johnson et al, 2011, pp. 121-123):

- Objectives and measurement. Some executives see that objectives are not useful unless their accomplishment can be measured. There are times when quantified targets need to be pursued, for example when a critical operation is needed and management needs to focus attention on a limited number of priority needs - as in the case of transformation;

- Define basic objectives. Managers in most firms determine financial objectives because they realize that unless sufficient earnings are made to satisfy shareholders and allow reinvestment in the business, it will not survive. However, there may be other features of business procedures that survive and thrive business. For example, how an organization is distinct from its competitors, or how competitive advantage can be achieved and maintained. This is likely to be based on the capabilities that are evaluated by the customers and distinct from the competition. Setting targets that capture this competitive advantage and allow performance monitoring against them is also crucial;

- Objectives and control. This can be addressed through a 'series of objectives - a set of comprehensive objectives are defined at each level in the hierarchy. Here consideration should be given to trade-offs: How to achieve the desired levels of visibility on strategy without being overly restrictive in terms of people's latitudes.

Strategic objectives are aims relating to strengthening a firm's overall market situation and competitive viability (Nábrádi, 2006, p. 30).

Strategic choices The strategic choice perspective goes one step further by proposing that not only do organizations adopt to a changing environment, but they also have the opportunity and power to reshape their environment (Wheelen and Hunger, 2012, p. 37). A reexamination of an organization's current mission and objectives must be made before alternative strategies can be generated and evaluated (Wheelen and Hunger, 2012, p. 205). Furthermore, the concept of competitive advantage must be the strategic choice of the organization, it must indicate unique opportunities for itself in the district of its choice and the characteristics of its products are individual so that it enjoys a strong competitive position. It may choose a large market share to control the markets and determine the shape of competition. It might choose to present the best products and services. (Dobson et al, 2004, p.9). 


\subsection{The Concept of Quality}

People's perception of quality varies from a person to another. However, everyone understands what is meant by "quality." In a manufactured product, the customer as a user realizes the quality of proper, look, finish and performance. Service quality may be rated based on the degree of customer satisfaction (Chandrupatla, 2009, pp. 1-10). "Quality" in the English Dictionary means the degree of excellence of something (Cambridge Dictionary). However, this definition is relative but the evaluation process depends on client opinion. Customer needs must be clear in measurable features in the product or service. Once the specifications have been developed, methods are needed to measure and monitor the characteristics. This provides a basis for continuous improvement in the product or service. The eventual goal is to make sure that the customer will be satisfied to pay for the product or service. This should result in a reasonable profit for the product or service provider. Relationship with customers is a lasting relationship. Product reliability plays an important role in the development of this relationship (Uncles et al, 2003).

Quality leader Crosby defined Quality is: the conformance to the requirements. Juran defined Quality as fitness for use. This definition focuses on the client that uses the product. W. Edwards Deming defined quality as: "Good quality means a predictable degree of uniformity and dependability with a quality standard suited to the customer" (Chandrupatla., 2009, pp. 1-10). Deming also argued that "Quality should be aimed at the needs of the customer, present and future" (Oakland, 1995, p.5). American Society for Quality (ASQ) adopted this definition of quality:" Quality denotes an excellence in goods and services, especially to the degree they conform to requirements and satisfy customers. Armand Feigenbaum pointed that Quality is a customer determination based upon a customer's actual experience with a product or service, measured against his or her requirements -stated or unstated, conscious or merely sensed, technically operational or entirely subjective -and always representing a moving target in a competitive market. Robert Peach, The ISO 9000 Handbook, pointed that quality is "...the totality of characteristics of an entity that bear on its ability to satisfy stated or implied needs (American Society for Quality, 2008). Quality is "providing goods and services that meet or exceed customer requirements" (Pekar, 1995, p.9).

\subsection{Service Quality}

Service industry takes more and more important part in the economy of many states. In today's worldwide competitive climate, providing high-quality service is a key strategy for achieving success and keeping existence (Munhurrun et al, 2010). Quality has been known as a strategic instrument to achieve operational capacity and enhanced business execution. This applies to both the goods and services sections (Jain and Gupta 2004). Quality begins and ends with the client. Customer must be the body and soul of the work (Reis and Peña, 2000). The organization must be customer focused. Everyone in the organization must realize that without the client there would be no aim to their business, no wages, no principal investment (Pekar, 1995). Companies that have learned to take care of their customers have achieved superior quality. An organization can only achieve improvement qualitatively if it makes customers a driving force. Companies achieving long-term continuous improvement in quality when they own lasting features such as customer tendency, customer awareness, and customer response (Reis and Peña, 2000). Service quality is required to build client satisfaction and it is linked with customer perceptions and customer anticipation. (Kabir and Carlsson, 2010). Service quality relates to attitudes exhibited by frontline employees when communicating with customers to treat their requirements and services, such as supplying adaptive and masterly service and being sympathetic, helpful, and interested to customers (Liao \& Chuang, (2004), cited in Aryee et al. (2013). Services of the Public sector are dependable and liable to populations as well as to its citizens (Munhurrun et al, 2010). Efficient services are recognized when the service provider respond to customer request and when all citizens have access to the services provided and when the administration work to ensure that the services match with the request for all consumers (Webster et al., 2011). When quality is available satisfied customers will increase in number, buy more, pay their bills promptly which improves cash flow and the livelihood of the organization (Nashappi et al., 2014).

There are some significant differences between services and goods. Services are intangible while goods are tangible. Since services are intangible, measuring service quality is more intricate. Quality of service measures how much provided service meets the client' expectations. (Grönroos, 1984; Lovelock and Wirtz, 2011) cited in Yarimoglu, 2014). In general, Quality products have three features: reliability, usability, and longevity. Quality of service is concerned with reliability, tangibles, responsiveness, assurance, and empathy (Asim and Zaki, 2012).

The researcher supposes that Quality of Service means that the organization plans, produces, and delivers the service with good features from the first time to achieve customer satisfaction and to have the benefit of competitive advantages compared to the service provided by similar organizations. 


\subsection{Quality Dimensions}

It has five common dimensions are stated as follows (Shahin, 2010, pp.3-4).

Tangibles: Tangibles are material objects of the service which include physical means; personnel manifestation; instruments or tools used to supply the service; physical representations of the service; and other customers in the service facility. (Parasuraman et al., 1985). This means that the equipment in the organization must be up-to-date; physical facilities must be visually attractive; the staff must be well dressed and look stylish and the appearance of the physical facilities should be consistent with the type of services (Yarimoglu, 2014).

Reliability: Reliability includes consistency of execution and confidence. This means that the organization accomplishes the service right the first time. Likewise, it means that the foundation fulfills its commitments. Specifically, it covers the accuracy in invoices; saving records correctly; completing the service at the specified time (Parasuraman et al., 1985). Furthermore, reliability means sympathy and reassurance for customers when they have problems (Parasuraman et al., 1988; Finn and Lamb, 1991, cited in Yarimoglu, 2014).

Responsiveness: According to Parasuraman et al., (1988) and Finn and Lamb, (1991) Yarimoglu (2014) argued that responsiveness is to give assistance to customers and offer instant service. Responsiveness concerns the desire or willingness of staff to supply service. It requires timing of service: sending the slip procedure instantly; calling the client again speedily and providing fast service (Parasuraman et al., 1985).

Assurance: Assurance is the kindness, understanding, the capability of employees to create trust and confidence, this means that: the public should be able to reliance on employees; customers should feel secure in their transactions with these organizations' employees; the employees must be courteous and employees must obtain sufficient support to do their works well (Parasuraman et al., 1988; Finn and Lamb, 1991, cited in Yarimoglu, 2014).

Empathy: Empathy (including access, means of connection, the understanding the client). Caring and personalized attention that the organization provides to its clients (Van Iwaarden et al., 2003; Shahin, 2006, cited in Shahin et al. 2010). Empathy includes: the organization should give customers individual attention to its customers; employees must give customers personal care; employees must know the needs of their customers; employees have customers' best interests at heart; and operating hours should be suitable to all customers (Parasuraman et al., 1988; Finn and Lamb, 1991, cited in Yarimoglu, 2014).

Jenin Municipality: Jenin city was founded in (2450) B.C.E, it is the largest and oldest city of the Jenin Governorate located in the northern West Bank. The city population is over $(39,000)$ people (www.globalcommunities.ps). The area of Jenin is $(21,000)$ acres, making it the third-largest Palestinian city in the West Bank after Hebron and Nablus. The first municipal council for Jenin was established in 1886 and the last elections were in 2017.Jenin city has a municipal council consisting of fifteen members (12) are males and (3) are females were elected directly by the city citizens. The municipality works to provide basic services to the citizens such as water, electricity, sanitation, cleanliness of public areas, etc. The municipality employs (357) workers, including administrative, vocational and field workers. The administrative are (140) of these workers, they are the study population and the research sample was selected randomly from them (Department of human resources in Jenin Municipality, 2017). After the adoption of strategic planning as a means of developing the local government sector in Palestine, Jenin Municipality formulated its strategic plan for the years (2012-2015) and the Municipality updates its plan annually (Jenin municipality, 2017).

\subsection{Previous Studies}

In this study, the researcher discusses some of the studies that dealt with strategic planning with its various components and the studies that dealt with the quality of its different dimensions. The research also discusses some studies that linked strategic planning and quality in performance. This part of the study concluded by commenting on these previous studies, explaining the similarities and differences between them with the current study and the extent of the current study benefited from previous studies. The researcher divided these studies into three parts: Local Studies; Arabic Studies; and International Studies.

Al-Habil and El-Ghazali, (2017) examine the impact of political based recruitment dimensions on the quality of governmental services in the public ministries of Palestine. The research investigated the impact of four main independent variables: independence of decision making, justice in giving governmental services, official labor abuse for personal benefit, and the organization self-autonomy. The researchers followed the statistical analytical method, they collected the required data by a questionnaire which was distributed to the public employees who work as department managers and managers in charge in ministries of the social sector. Outcomes showed that decisions making independence and justice in giving governmental services have a significant effect on the 
quality of governmental services. The research recommended applying the principle of fair opportunities in the appointment of senior positions in senior Palestinian public positions.

Nashappi et al., (2014) tested the impact of strategic planning on the quality of service Nashappi et al., (2014) did a research about "Attributes That Influence Customer Satisfaction with Service Quality at Kenya Power Company", which aimed at establishing the critical service quality attributes and evaluating the factors leading to customer satisfaction as well as assess the challenges customers face in obtaining quality service from KP. The researchers used a descriptive research and a stratified random sample of 125 people, they collected data by using a structured questionnaire. The study findings indicated that most customers were satisfied with the attributes of tangibility and assurance. The customers were not satisfied with the service aspects of reliability and responsiveness of the organization as well as with notification of impending outages. The researchers recommended that the organization ought to check solving its customer claims and find a technique for following customer satisfaction. The organization has to set up an efficient technique to follow on its products and services.

Salkić, (2014 define the impact of strategic planning on the management of public organizations by knowing and determining the way and how strategic planning leads to manage public organizations with more responsibility in Bosnia and Herzegovina. An empirical study was undertaken in public organizations in Bosnia and Herzegovina, Questionnaires were sent by e-mail to the respondents - senior managers of public organizations were selected for the sample. A specific application was used to gather answers. The findings of the research point out that using of strategic planning in public institutions allow more logical, effective and successful management of organizational resources and implementation of strategic planning in public organizations in Bosnia and Herzegovina assists directors to direct public organizations in a more accountable way.

Al-Shikh (2014) study aimed to know the impact of strategic planning on banking services in Sudan and the extent of correlation between strategic planning and the quality of banking processes with its various dimensions: tangibility, reliability, response, security and sympathy. The researcher used the questionnaire to collect information. The study found significant results, which is that the quality of service in banks exist in four dimensions, strategic planning more closely associated with the response and security, and less correlated with other dimensions of empathy and tangibility, the study recommended that senior management should put in their strategic plans programs about how to provide service to customers and to take into consideration the dimensions of quality.

\section{Methodology}

This chapter contains and discusses the research methodology that used to conduct the research results. It clarifies the data collection method and sample selection. Moreover, it describes the manner of research questionnaire design and verifies the validity and reliability of research questionnaire. This chapter also identifies the study measurement tools and statistical approaches that used in the study. The researcher used the analytical descriptive method, where she returned to the previous literature on the subject to clarify the theoretical background of the study. The data were then analyzed and processed statistically to extract and compare the results.

\subsection{Data Collection}

Data collection is the process of collecting the required data for the selected group in the research (Statistics Canada, 2010, p. 37). The sources of data collection in this study were the primary data and secondary data.

Primary Data:The main source of data to be used in this study is the questionnaire. The questionnaire design defined as an outline for data collection, measurement, and analysis as its function is providing a collection of relevant evidence. This method is common in collecting information, it is being adopted by specific individuals, research workers, private and public institutions and even by governments (Kothari,2004, p. 96). A questionnaire is a data collection tool consisting of a group of questions for the aim of collecting data from respondents. The questionnaire was developed by Sir Francis Galton (Abawi, 2013). The current study aims to examine the impact of strategic planning in Jenin municipality on the quality of service provided to citizens. Based on the literature and previous studies, a questionnaire was designed to collect data about the subject by the researcher, to answer research questions and to test its hypothesis.

Secondary Data: Which is the data that collected by other researchers that originally collected for other schooling purposes, as: journals, books, bulletins, textbooks, scientific articles, newspapers, periodicals. etc. 


\subsection{Study Instruments}

The researcher adopted SERVQUAL model in this study and made some adaptation on it to match the main objectives of the study which is to know the impact of adopting strategic planning in Palestinian Municipalities on the quality of service provided to citizens. SERVQUAL is an advanced model for evaluating service quality which was developed by Parasuraman et al. in (1988). In SERVQUAL model, there are five dimensions and (22) items presented in seven-point Likert scale were used to measure especially functional service quality in banking. These dimensions are Tangibles, Reliability, Responsiveness, Assurance, and Empathy (Shahin, 2011).

Questionnaires function a major role in the information collection process. They have a great impact on data quality. They also affect the image that the statistical organization projects to the public. The questions developed must comply with the study statement of objectives and provide details that are useful for data analysis. All information requirements should be met (Statistics Canada, 2010, p. 55).

The researcher developed a questionnaire by reviewing the references and previous studies related to the study (Al-Shikh, 2014; Qasim. 2012; Ramseook et al., 2010; Markovic' and Raspor, 2010; Ilias, A. et al, 2008). The researcher adopted SERVQUAL model in this study and made some adaptation on it to match the main objectives of the study. The questionnaire consisted of two parts:

Part 1: General information about the sample study

Part 2: Includes instructions on how to answer the paragraphs of the questionnaire, in addition to the presentation of paragraphs of the questionnaire, which was distributed on two main dimensions as follows:

First Dimension: Strategic Planning (independent variable), which consists of four fields: Vision: A description of the future aspirations of the municipality. Mission: The current orientation of the municipality is determined in its current activities and the needs of the citizens that the municipality works to meet. Objectives: the desired final outcomes of the planned activities. Strategic Choices: decisions are chosen from a set of alternatives and are considered the best way to achieve the objectives of the municipality (Strategic management questionnaire, www.amces.com).

Second Dimension: Quality (dependent variable), which consists of five fields: Tangibles: physical facilities, equipment, the appearance of staff. Reliability: Ability to perform the promised service reliably and accurately. Responsiveness: The readiness of the municipality to help citizens and provide prompt service upon request. Empathy: access, communication and understanding of the citizen, care and individual attention provided by the municipality to the citizen. Assurance: efficiency, credibility, security, knowledge, and courtesy of employees and their ability to inspire self-confidence (Shahin \& Samea, 2010, p. 2)

\subsection{Study Model}

The overall objective of this study is to find out the impact of strategic planning factors on the quality of service provided to citizens by Jenin municipality. Municipalities must measure its customers' satisfaction level to improve their relationship with citizens and deliver services beyond customer expectations with good quality. The conceptual framework of this study is developed from literature review mentioned in above. Relying on this framework Quality Dimensions are the key component for citizens' satisfaction. Therefore, the researcher in this study set the conceptual framework to guide this study as follows in figure (4).

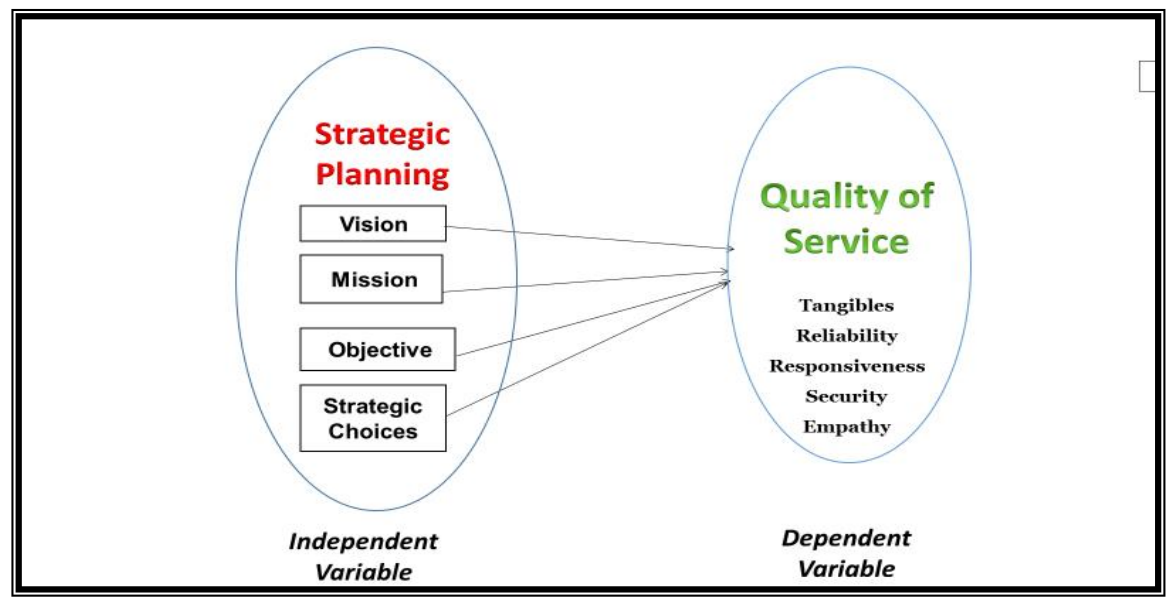

Figure 4. illustrate the Impact of Strategic Planning in Palestinian Municipalities on the Quality of Service 


\section{Questionnaire Validity}

The questionnaire passed through several steps before distributing the final version to the target respondents, the questionnaire has been reviewed and verified by specialized arbitrators and academics who have experience. It sent to seven evaluators and the researcher supervisor to evaluate each item/question and its consistency to reach the main objectives of the study. See Appendix (2). The questionnaire was examined in a pilot study on a sample of (30) respondents from two municipalities (Ya'bad and Arrabah) in Jenin Governorate.

\section{Questionnaire Reliability}

The researcher verified the reliability statistics for the fields scale to calculate the coefficient of stability through the equation (Cronbach's Alpha), where the value of the stability factor on the overall fields according to the equation Cronbach's Alpha (0.968), whereas the acceptable Alpha value that meets the statistical requirement for the instrument to be characterized as reliable should be equal or above is $(0.70)$ according to Tavakol, M.\& Dennick, R. (2011).Therefore, the measurement model is proved to be adequate, as shown in Table (1):

Table 1. Cronbach's Alpha coefficient of consistency for the Tool

\begin{tabular}{lll}
\hline Field & No. of Items & Cronbach's Alpha \\
\hline Vision & 4 & 0.854 \\
Mission & 4 & 0.857 \\
Objectives & 4 & 0.906 \\
Strategic Choices & 3 & 0.871 \\
Strategic Planning & 15 & 0.958 \\
Tangibles & 9 & 0.839 \\
Reliability & 5 & 0.829 \\
Responsiveness & 5 & 0.885 \\
Empathy & 6 & 0.799 \\
Assurance & 5 & 0.877 \\
Quality of Services & 30 & 0.947 \\
\hline
\end{tabular}

\subsection{Study Procedures}

The researcher carried out the following procedures:

- Access to literature and previous studies related to the study.

- Preparation of study tools include building a tool to determine the reality of academic difficulties and future directions.

- Arbitration of the study tools by the competent arbitrators and the introduction of their amendments.

- Obtaining a letter to facilitate the research mission from the Faculty of Graduate Studies at the Arab American University and obtain official permission from the Municipality of Jenin to apply the study to the staff of the Municipality of Jenin and meet those who are asked to serve the research objectives (see Appendix 3).

- Apply the study tool (the questionnaire) to the study sample.

- Monitoring and analyzing results in special tables.

- Presenting, discussing and making recommendations in light of the results.

\subsection{Measurement}

The impact of adopting Jenin municipal strategic planning on the quality of services provided to citizens in Jenin city is measured using a five-point Likert scale- Level of Agreement (Vagias, 2006) which consists of five items ranging from $\mathbf{1}$ (strongly disagree) to $\mathbf{5}$ (strongly agree).

\subsection{Population and Sample}

The study population consists of (140) office staff of Jenin Municipality, (28) of them are women representing (20\%) of the staff. The number of employees is classified as follows: (9) department directors, (29) heads of division/section and (102) classified as employees. The questionnaire was distributed to all members of the study sample as shown in Table (4).

The minimum sample of the study consisted of (103) employees, (120) questionnaires were distributed, (114) questionnaires were retrieved and (6) cases were (missing cases). A minimum sample was chosen according to Steven K. Thompson formula, (Thompson, S. K. 2006).

\section{Study Results}

In order to achieve the main objective of this study "the impact of strategic planning in the Palestinian 
municipalities on the quality of service provided to citizens "Jenin Municipality: Case Study ", the data was collected by a questionnaire from the field (Jenin municipality) and analyzed statistically. This chapter presents the data analyses and the findings of the study. In addition to the participants' profile, the answers to the study questions and testing the hypotheses.

As shown in the table (2), out of a total of 114 respondents: the males represent $85.1 \%$ of the sample while female represents only $14.9 \%$.

Table 2. Demographic distribution of respondents

\begin{tabular}{|c|c|c|c|}
\hline Variable & & Frequency & Percentage \\
\hline \multirow[t]{3}{*}{ Gender } & Male & 97 & $85.1 \%$ \\
\hline & Female & 17 & $14.9 \%$ \\
\hline & Total & 114 & $100 \%$ \\
\hline \multirow[t]{5}{*}{ Academic qualification } & Secondary & 43 & $37.7 \%$ \\
\hline & Diploma & 20 & $17.5 \%$ \\
\hline & bachelor's & 48 & $42.1 \%$ \\
\hline & master's or higher & 3 & $2.6 \%$ \\
\hline & Total & 114 & $100 \%$ \\
\hline \multirow[t]{5}{*}{ Age group } & less than 25 years & 3 & $2.6 \%$ \\
\hline & $25-35$ & 31 & $27.2 \%$ \\
\hline & $36-45$ & 38 & $33.3 \%$ \\
\hline & greater than 45 & 42 & $36.8 \%$ \\
\hline & Total & 114 & $100 \%$ \\
\hline \multirow[t]{4}{*}{ Job Status } & Employee & 79 & $69.3 \%$ \\
\hline & Head of Division/Section & 26 & $22.8 \%$ \\
\hline & Director & 9 & $7.9 \%$ \\
\hline & Total & 114 & $100 \%$ \\
\hline \multirow[t]{5}{*}{ Years of Experience } & less than 3 years & 6 & $5.3 \%$ \\
\hline & $3-6$ years & 8 & $7.0 \%$ \\
\hline & $7-10$ years & 12 & $10.5 \%$ \\
\hline & more than 10 years & 88 & $77.2 \%$ \\
\hline & Total & 114 & $100 \%$ \\
\hline
\end{tabular}

\subsection{Results of the First Question}

This section will answer the study questions, from the perspective of the employees of Jenin municipality to identify the current status of strategic planning in Jenin municipality and the quality of service provided to citizens.

"What is the degree of the available strategic planning in Jenin municipality?"

Table 3. Statistical Means, standard deviations and percentage of strategic planning factors according to respondents' responses

\begin{tabular}{llllll}
\hline No. & Field & Mean & $\begin{array}{l}\text { Standard } \\
\text { Deviations }\end{array}$ & \% & Degree \\
\hline 1 & Vision & 2.63 & 0.97 & 52.7 & Moderate \\
2 & Mission & 2.59 & 0.97 & 51.8 & Moderate \\
3 & Objectives & 2.67 & 1.03 & 53.4 & Moderate \\
4 & Strategic Choices & 2.60 & 1.05 & 52.0 & Moderate \\
& Strategic Planning & $\mathbf{2 . 6 2}$ & $\mathbf{0 . 9 3}$ & $\mathbf{5 2 . 5}$ & Moderate \\
\hline
\end{tabular}

Results shows that the mean of the Strategic Planning is (2.62) with a standard deviation of (0.93), with about $(42.9 \%)$. This indicates that the strategic planning is moderate from the point of view of respondents. This applies to all the four factors with a simple difference. This means that the employees have little information about the reality of strategy in their workplace, as shown in the tables: from (7-10). Results shows the value of each item in the field "vision", it indicates that the item:" The municipality has a clear and understandable vision for citizens " has the highest score among the items, with mean value of (2.80) out of five, (56.0\%) agree with Standard Deviations is (1.17). By contrast, the item "Vision takes into account the capabilities and competencies available in the municipality and expected obstacles." has the lowest score among the items with a mean value of (2.35) out of five. In general, the "Vision" field classified as a " Moderate" degree within all its items. The findings pointed that the Vision of the municipality should take into account the capabilities and competencies available in the municipality and expected obstacles. Results shows the value of each item in the field "Mission", it indicates that the item:"The municipality's current mission is consistent with its activities" has the highest score among the items, with mean value of (2.66) out of five, (53.2\%) agree with Standard Deviations is (1.13). By contrast, the item "I participate in developing the municipal mission." has the lowest score among the items with mean value of (2.46) out of five. In general, the "Mission" field classified as a "Moderate" degree within all 
its items. The results pointed that most of employees didn't participate in developing the municipal mission. result shows that the mean of the total score for Objectives' field is (2.67) with a standard deviation of (1.03) and has (53.4\%). This indicates that the Objectives' field is Moderate from the point of view of respondents, and this applies to all the four items. It indicates that the item:" The municipality has long-term goals." has the highest score among the items, with a mean value of (2.81) out of five, (56.1\%) agree with Standard Deviations is (1.18). By contrast, the item "The objectives are developed with the participation of all parties responsible for their implementation." has the lowest score among the items with mean value of (2.60) out of five. In general, the " Objectives" field classified as a " Moderate" degree within all its items. The results show that not all responsible parties participate in developing objectives. Result shows that the value of each item in the field "Strategic Choices' ", it indicates that the item:" The municipality works on implementing its plans." has the highest score among the items, with mean value of (2.69) out of five, (53.9\%) agree with Standard Deviations is (1.17), while the item "The municipality develops strategic choices to treat the issues it faces." has the lowest score among the items with mean value of (2.53) out of five. In general, the "Strategic Choices'" field classified as a " Moderate" degree within all its items.

\subsection{Results of the Second Question}

"What is the level of the quality of service provided to citizens in Jenin municipality?" Based on the statistical means, standard deviations and percentage of quality dimensions, as shown in table 4, it displays that the overall of these dimensions was high.

Table 4. Statistical Means, standard deviations and percentage of the "quality of service" Dimension according to respondents' responses

\begin{tabular}{llllll}
\hline No. & Field & Mean & $\begin{array}{l}\text { Standard } \\
\text { Deviations }\end{array}$ & $\%$ & Degree \\
\hline 1 & Tangibles & 3.29 & 0.73 & 65.8 & Moderate \\
2 & Reliability & 2.92 & 0.90 & 58.4 & Moderate \\
3 & Responsiveness & 2.93 & 0.94 & 58.6 & Moderate \\
4 & Empathy & 3.25 & 0.79 & 65.0 & Moderate \\
5 & Assurance & 2.68 & 0.96 & 53.6 & Moderate \\
& Quality of Service & 3.06 & 0.71 & 61.2 & Moderate \\
\hline
\end{tabular}

As shown in table (4) also, the value of each field in the quality of service dimensions, indicates that the field:" Tangibles" has the highest score, with mean value of (3.29) out of five, $(65.8 \%)$ agree with standard deviations is (0.73), while the field "Security" has the lowest score among the items with mean value of (2.68) out of five. In general, the "Quality of Service Dimension" classified as a "Moderate" degree. This explains that the level of satisfaction of the quality of the services provided by the municipality which is measurable by employees was moderate, and the result was positive. result shows the value of each item in the field "Tangibles", it indicates that " The organization and internal arrangement of the citizens' service center provide comfort to the public" has the highest score among the items, with a mean value of (3.98) out of five, (79.6\%) agree. By contrast, "Citizens benefit from the modern information communication network." has the lowest score among the items with a mean value of (2.88) out of five. In general, the Tangibles field classified as a "Moderate" degree within the quality of services with the mean value of (3.29) out of five, (65.8\%) agree. It was found that the organization and the internal arrangement of the Citizen Service Center were appreciated by all employees. In contrast, citizens do not benefit from the modern communications network. result shows the value of each item in the field "Reliability", it indicates that " The Municipality announces all data and information relating to the new services" has the highest score among the items, with a mean value of (3.20) out of five, (64.0\%) agree. By contrast, "The municipality provides its services at the time it promises to do so" has the lowest score among the items with a mean value of (2.44) out of five. In general, the Reliability field classified as a "Moderate " degree within the quality of service.

This means that all the data and information relating to the new service are announced by the municipality, but the municipality didn't provide its services at the time it promised to do.

result shows the value of each item in the field " Responsiveness", it indicates that " There is a complaint box in the municipality" has the highest score among the items, with a mean value of 3.11 out of five, $62.1 \%$ agree. While the item " The municipality deals with citizens' complaints as transparently and quickly as possible" has the lowest score among the items with a mean value of 2.72 out of five. In general, the Responsiveness field classified as a "Moderate" degree within the quality of services. It is clear that the municipality is interested in the issue of complaints, and the employees follow up and respond to citizens immediately. While a little effort is being made for dealing with citizens' complaints as transparently and quickly as possible. result shows the value of each item in the field " Empathy ", it indicates that " The municipality's work time is suitable for citizens" has 
the highest score among the items, with mean value of (3.80) out of five. While the item "The municipality follows the citizens' observations with interest" has the lowest score among the items with mean value of (2.79) out of five. In general, the Empathy field classified as a "Moderate" degree within the quality of service. It is observed that the work time of the municipality is suitable for citizens, and it is concerned with visitors with physical disabilities. But it was noted that the municipality does not follow the citizens' comments with seriousness and interest. result shows the value of each item in the field "Assurance", we noticed that the rate and all its items were also a Moderate degree, it indicates that " The citizen obtains some services by phone" has the highest score among the items, with a mean value of (2.99) out of five. By contrast, "The municipality conducts a periodic assessment of employees to identify their strengths and weaknesses" has the lowest score among the items with a mean value of (2.22) out of five. The results indicate that the municipality should conduct a periodic evaluation of employees to identify the employee's strengths and weaknesses.

\subsection{Testing Hypotheses}

H0.1: There is no significant relationship between the strategic planning factors (vision, mission, objectives, strategic choices) and the quality of service dimensions (tangibility, reliability, responsiveness, security, assurance) in Jenin municipality at the level $\alpha \leq 0.05$.

The person correlation coefficient test technique was used to test the above hypothesis.

Table 5 shows that the value of Person Correlation between the quality of service and the strategic planning is $(0.760)$ and significant at $(0.000)$ level between the total value of the quality and the total value of the strategic planning, also between each factor of them. Pearson correlation matrix among the quality of service and the strategic planning factors presented that there is a strong significant positive relationship between the total value of the quality and each of vision, mission, objectives, and strategic choices, where ( $r=0.695, p<0.01),(r=.706$, $\mathrm{p}<0.01),(\mathrm{r}=.703, \mathrm{p}<0.01)$, and $(\mathrm{r}=.706, \mathrm{p}<0.01)$ respectively.

Table 5. Correlation Coefficients among Quality of Service Dimensions and Strategic Planning Factors

\begin{tabular}{|c|c|c|c|c|c|c|c|c|c|c|c|}
\hline Factors & 1 & 2 & 3 & 4 & 5 & 6 & 7 & 8 & 9 & 10 & 11 \\
\hline Vision & 1 & & & & & & & & & & \\
\hline Mission & $.811^{* *}$ & 1 & & & & & & & & & \\
\hline Objectives & $.835^{* *}$ & $.813^{* *}$ & 1 & & & & & & & & \\
\hline Strategic Choices & $.787^{* *}$ & $.763^{* *}$ & $.800^{* *}$ & 1 & & & & & & & \\
\hline Tangibles & $.453^{* *}$ & $.427^{* *}$ & $.452^{* * *}$ & $.522^{* *}$ & 1 & & & & & & \\
\hline Reliability & $.738^{* * *}$ & $.719^{* *}$ & $.720^{* * *}$ & $.682^{* *}$ & $.533^{* *}$ & 1 & & & & & \\
\hline Responsiveness & $.631^{* *}$ & $.663^{* *}$ & $.593^{\text {** }}$ & $.620^{* *}$ & $.457^{* *}$ & $.799^{* *}$ & 1 & & & & \\
\hline Empathy & $.582^{* *}$ & $.632^{* * *}$ & $.602^{* * *}$ & $.546^{* *}$ & $.484^{* *}$ & $.744^{* * *}$ & $.787^{* *}$ & 1 & & & \\
\hline Assurance & $.588^{* *}$ & $.609^{* * *}$ & $.658^{* * *}$ & $.641^{* *}$ & $.559^{* *}$ & $.753^{* *}$ & $.779^{* *}$ & $.690^{* *}$ & 1 & & \\
\hline Quality & $.695^{\text {** }}$ & $.706^{* *}$ & $.703^{* *}$ & $.706^{* *}$ & $.755^{\text {** }}$ & $.885^{\text {*** }}$ & $.879^{* *}$ & $.856^{* *}$ & $.880^{* *}$ & 1 & \\
\hline Strategic & $.933^{* *}$ & $.920^{* *}$ & $.939^{* *}$ & $.897^{* *}$ & $.498^{* *}$ & $.776^{* * *}$ & $.679^{* *}$ & $.642^{* *}$ & $.675^{* *}$ & $.760^{* *}$ & 1 \\
\hline
\end{tabular}

**: confidence level at 0.01 .

This indicates that the results support the alternative hypothesis to reject $\mathrm{H} 0$ and accept the alternative hypothesis that says "there is a significant relationship between the strategic planning factors (vision, mission, objectives, strategic choices) and the quality of service dimensions (tangibility, reliability, responsiveness, security, assurance) in Jenin municipality at the level $\alpha \leq 0.05$ ". It is observed that the correlation coefficient between each indicator in the dimension of strategic planning and each indicator in the dimension of quality of services provided is significant at the $(0.01)$ level. Moreover, it is observed that the correlation coefficients have positive signs. This means that the factors of strategic planning and the dimensions of quality of service provided are positively related.

Moreover, this hypothesis gives the answer of the third question which was: "Is there a relationship between the strategic planning factors (vision, mission, objectives, strategic choices) and the quality of service dimensions (tangibility, reliability, responsiveness, security, assurance) in Jenin municipality?"

\section{The Second Hypothesis}

H0: There is no significant impact of strategic planning factors (vision, mission, objectives, strategic choices) on the quality of service dimensions (tangibility, reliability, responsiveness, security, assurance) in Jenin municipality at the level $\alpha \leq 0.05$.

The multiple linear regression techniques are used to test the above hypothesis since we are interested in investigating the impact of the adopting Jenin municipality the strategic planning factors (vision, mission, objectives and strategic choices) on the dependent variable (quality of service provided to citizens in Jenin city). 
Table 6. R-square and ANOVA ${ }^{\mathrm{b}}$ for Quality of services model

\begin{tabular}{lllllllll}
\hline Model & Sum of Squares & Df & Mean Square & F & Sig. & R & R Square & Adjusted R Square \\
\hline Regression & 33.363 & 4 & 8.341 & 38.040 & .000 & $.763^{\mathrm{a}}$ & .583 & .567 \\
Residual & 23.900 & 109 & .219 & & & & & \\
Total & 57.262 & 113 & & & & & & \\
\hline
\end{tabular}

The results from table (6), using the ANOVA test, shows that the overall regression model is significant at the $(0.000)$ level with F-value of (38.04). This means that the strategic planning factors in this model explain the variation in the quality of services provided to citizens in Jenin city. The value of R-square of (0.583) indicates that the model explains nearly $(58.3 \%)$ of the quality of service, also multiple correlation coefficients " $\mathrm{r}=(0.763)$ " shows positive and strong linear relationship between dependent variable "quality of service" and the predictors.

Table 7. Regression Model Using the "Quality " as a Dependent Variable

\begin{tabular}{|c|c|c|c|c|c|c|}
\hline \multirow{2}{*}{\multicolumn{2}{|c|}{$\begin{array}{l}\text { Constant } \\
\text { variables/factors }\end{array}$}} & \multicolumn{2}{|c|}{ Unstandardized Coefficients } & $\begin{array}{l}\text { Standardized } \\
\text { Coefficients }\end{array}$ & \multirow[t]{2}{*}{$\mathrm{T}$} & \multirow[t]{2}{*}{ Sig. } \\
\hline & & B & Std. Error & Beta & & \\
\hline (Constant) & & 1.528 & .133 & & 11.486 & .000 \\
\hline Vision & & .101 & .094 & .138 & 1.079 & .283 \\
\hline Mission & & .185 & .087 & .252 & 2.119 & .036 \\
\hline Objectives & & .112 & .090 & .162 & 1.233 & .220 \\
\hline Strategic Choices & & .187 & .077 & .276 & 2.441 & .016 \\
\hline
\end{tabular}

It was found that the mission significantly predicted the quality of service, as the strategic choices did with ( $\beta=$ 0.252 , Sig. $=0.036)$ and $(\beta=0.276, \mathrm{Sig} .=0.016)$ respectively.

The model equation for the quality of service is:

Quality of service $=1.528+0.185$ mission +0.187 strategic choices.

The interpretations of the significant independent variables:

1) There is a direct impact of the mission on the quality of service and increasing mission by (10) units may increase the quality of service by (2.52) units.

2) There is a direct impact of the strategic choices on the service quality and increasing strategic choices by (10) units may increase the quality of service by (2.76) units.

3) There is no significant impact of (vision, objectives), that means there is no impact for these predictor variables (vision, objectives) on the quality of service.

This indicates that the results support the alternative hypothesis so we reject $\mathrm{HO}$ and accept the alternative hypothesis that says "there is a significant impact of strategic planning on the quality of service".

\section{Recommendations}

According to the conclusions above the researcher suggest a set of recommendations which are:

1- Involve women and youth in the work at all levels of administration in Jenin municipality;

2- It is preferable that Jenin municipality increase staff participation in the strategic planning and updating of the municipality's strategic plan;

3- It is preferable for the municipality to formulate an obvious mission which corresponds with its activities strongly;

4- It is preferable for Jenin municipality vision take into account the capabilities and efficiencies available in the municipality and the expected obstacles;

5- It is useful for Jenin municipality to strive to develop strategic options which are valid to the conditions it faces;

6- It is valuable for the municipality to provide its services at the time it promises to do so;

7- It is valuable if the municipality give more attention in dealing with citizens' complaints as transparently and quickly as possible;

8- Jenin municipality ought to spread awareness among the citizens about the modern communications network so that citizens can benefit from it.

9- The municipality has to follow the citizens' comments with seriousness and interest.

10-Jenin municipality should conduct a periodic evaluation of employees to identify the employee's strengths and weaknesses; 
11-Promote quality culture and encourage employees to participate in continuous improvement processes and opportunities for creativity and innovation;

12-Furthermore, other similar studies are recommended and the quality of service to be assessed from the perspective of the citizens who receive the service because they are the most capable of evaluating it.

Finally, the researcher hopes that the results of this study will benefit Jenin municipality and other Palestinian Municipalities to provide more attention to linking strategic planning with service quality and to consider the recommendations above.

\section{References}

A. Hutton, (2001). Communicating effectively with the investing community essential, as discussed by 'Four rules'. Harvard Business Review, 79(5), 125-132.

Abawi, K. (2013). Data collection instruments (questionnaire \& interview). Geneva: Geneva Foundation for Medical Education and Research.

Ajagbe, A. M. (2011). The relationship between strategic planning and the effectiveness of marketing operations. International Journal of Innovation Management and Technology, 2(5), 390-396.

Al-Ghazali, S. K. (2016). The impact of political based recruitment's dimensions on the quality of governmental services in Palestinian Public institutions. The impact of political based recruitment's dimensions on the quality of governmental services in Palestinian Public institutions.

Al-Qeeq, F. (2015). The role of community participation in sustainable development: Strategic development plans of Palestinian cities as a case study, University of Palestine Journal for researches and studiesnumber VIII January 2015, pp. 130-152. (in Arabic)

AlShibly, H. H., Louzi, B. M., \& Al-Kaied, N. (2014). The relationship between information quality and organization strategic benefit: an applied study on commercial banks. Information and Knowledge Management, 4(2), 22-36.

American Society for Quality. April (2008), Southern Connecticut Section 301, retrieved September 19, 2017 from http://asq.org/sections/mini sites/0301/newsletter_200804.pdf

Aryee, S., Walumbwa, F. O., Seidu, E. Y., \& Otaye, L. E. (2016). Developing and leveraging human capital resource to promote service quality: Testing a theory of performance. Journal of Management, 42(2), 480-499. https://doi.org/10.1177/0149206312471394

Asim, M., \& Zaki, A. R. (2012). Assessing the Viability of Quality Management in Organizations-A Retrospective and Prospective Overview with Reference to Pakistan.

Balogun, J., \& Hailey, V. H. (2008). Exploring strategic change. Pearson Education.

BērziHs, G. (2010). Strategic Management, Project „Development and Approbation of Applied Courses Based on the Transfer of Teaching Innovations in Finance and Management for Further Education of Entrepreneurs and Specialists in Latvia, Lithuania and Bulgaria", part of the Leonardo da Vinci programme. UNIVERSITY OF LATVIA.

BērziHs, G. (2015). Project Development and Approbation of Applied Courses Based on the Transfer of Teaching Innovations in Finance and Management for Further Education of Entrepreneurs and Specialists in Latvia, Lithuania and Bulgaria", part of the Leonardo DA Vinci program

Brecken, D. (2004). Leadership vision and strategic direction. The Quality Management Forum, 30(1), 1-7.

Cambridge Dictionary, retrieved September 19, 2017, from http://dictionary.cambridge.org/dictionary/english/quality

Carlsson, T. (2010). Service Quality: Expectations, perceptions and satisfaction about Service Quality at Destination Gotland-A case study.

Carpenter, Mason, \& Bauer, Talya, \& Erdogan, Berrin, (2012), Management Principles, this book was accessible as of December 29, 2012, and it was downloaded then by Andy Schmitz (http://lardbucket.org) in an effort to preserve the availability of this book.

Chandrupatla, T. R. (2009). Quality and reliability in engineering (Vol. 2). New York, NY: Cambridge University Press.

David, F. R. (2011). Strategic Management, Concepts and Cases Thirteenth. 
Debrah, K. P. (2012). The effect of strategic planning on the performance and operations of the Agricultural Development Bank (Doctoral dissertation).

Denhere, W., Tafirei, F., Zivanai, O., Muchingami, L., \& Chingarande, A. (2011). The quality of service delivery in Zimbabwean urban councils: a case study of Bindura municipality 2009 to 2011.

Di Napoli, T. P. (2003). Local Government Resource Handbook Strategic Planning. Retrieved April 17, 2017, from https://www.osc.state.ny.us/localgov/pubs/lgmg/strategic_planning.pdf, Division of Local Government and School Accountability Original Issue Date August 2002.

Dobbie, M. J., Henderson, B. L., \& Stevens Jr, D. L. (2008). Sparse sampling: spatial design for monitoring stream networks. Statistics Surveys, 2, 113-153. https://doi.org/10.1214/07-SS032

Dobson, P. W., Starkey, K., \& Richards, J. (2009). Strategic management: issues and cases. John Wiley \& Sons.

Edwards, L. H. (2011). Strategic planning in local government: is the promise of performance a reality? (Doctoral dissertation, Georgia Institute of Technology).

Finn, D. W. (1991). An evaluation of the SERVQUAL scales in a retailing setting. ACR North American Advances.

Gates, L. P. (2010). Strategic planning with critical success factors and future scenarios: An integrated strategic planning framework (No. CMU/SEI-2010-TR-037). CARNEGIE-MELLON UNIV PITTSBURGH PA SOFTWARE ENGINEERING INST. https://doi.org/10.21236/ADA532574

Gupta, T. (2017). Collecting Baseline Socio-Economic Data for Socio-Economic Impact Assessment: The Metlakatla Membership Census.

Haltina, V., Nordlund, J., Yli-Hukkala, K. Total Quality Management by John S. Oakland, retrieved September 29,2017 from http://www.iem.unifei.edu.br/turrioni/PosGraduacao/PQM07/TQM_aula_2_e_3/TQMbyOakland.pdf

Hasan, H. F. A., Ilias, A., Rahman, R. A., \& Razak, M. Z. A. (2008). Service quality and student satisfaction: A case study at private higher education institutions. International Business Research, 1(3), 163-175.

Ishikawa, K. (1985). What is total quality control? The Japanese way. Prentice Hall.

Jain, S. K., \& Gupta, G. (2004). Measuring service quality: SERVQUAL vs. SERVPERF scales. Vikalpa, 29(2), 25-38. https://doi.org/10.1177/0256090920040203

Kothari, C. R. (2004). Research methodology: Methods and techniques. New Age International.

Mohammed, A., Gichunge, E., \& Were, E. (2017). Relationship between strategic planning practices and performance of tour firms in the tourism sector in Kenya: A survey of selected tour firms in Nairobi, Kenya. International Academic Journal of Human Resource and Business Administration, 2(3), 521-534.

Msosa, S. K. (2015). Assessing customer service in the Malawian public postal service (Doctoral dissertation).

Musleh, A. (2010). The reality of strategic planning in the government ministries in Qalqilya Governorate from the perspective of its employee, Al-Quds Open University, Qalqilya Educational Zone. (in Arabic).

Musleh, A. (2011). Measuring the quality of services from the perspective of staff and patients in hospitals operating in the city of Qalqilya, Al-Quds Open University, Qalqilya Educational Zone, Retrieved July 2,7017, From; http://www.qou.edu/home/sciResearch/researchersPages/atiehMusleh/r4_drAtiehMusleh.pdf (in Arabic).

Nábrádi, A. (2006). Strategic Management Process: An Introduction, University of Debrecen, Faculty of Ag. Economics and Rural Development, Dept.: Business Management and Marketing, HUNGARY.

Nashappi et, al., (2014). Attributes That Influence Customer Satisfaction with Service Quality at Kenya Power Company, April, 2014, Vol. 3 Issue 4. P.p. 239-247, www.ijird.com.

Nickols, F. (2016). Strategy, Strategic Management, Strategic Planning and Strategic Thinking, Retrieved July 11, 2017, from http://www.nickols.us/strategy_etc.pdf

Oakland, J. S. (1995). Total Quality Management- The route to improving performance, Butterworth-Heinemann; 2 editions, p.9.

Parasuraman, A., Zeithaml, V. A., \& Berry, L. L. (1985). A conceptual model of service quality and its implications for future research. Journal of Marketing, 49(4), 41-50.

https://doi.org/10.1177/002224298504900403 
Parasuraman, A., Zeithaml, V. A., \& Berry, L. L. (1988). Servqual: A multiple-item scale for measuring consumer perc. Journal of retailing, 64(1), 12.

Part of the Leonardo da Vinci programme, (2010), "Project Development and Approbation of Applied Courses Based on the Transfer of Teaching Innovations in Finance and Management for Further Education of Entrepreneurs and Specialists in Latvia, Lithuania and Bulgaria",

Patton, J. R. (2007). Metrics for knowledge-based project organizations. SAM Advanced Management Journal, 72(1), 33-45.

Pekar, J. P. (1995). Total Quality Management. ASTM publication.

Qasim, R. S. (2012). The impact of organizational commitment on improving the quality of banking service, An applied study on a sample of Jordanian commercial banks. In partial fulfillment of the requirement for Master's degree in Business Administration, Middle East University. (in Arabic)

Ramseook, M. P., Lukea, B., Soolakshna, D., \& Naidoo, P. (2010). Service Quality in the Public Service. International Journal of -Management and Marketing Research, 3(1), 37-50, 2010. Available at SSRN: https://ssrn.com/abstract=1668833.

Raspor, S. (2010). Measuring Perceived Service Quality Using SERVQUAL: A Case Study of the Croatian Hotel Industry. Management (18544223), 5(3).

Reis, D., \& Peña, L. (2000), Linking Customer Satisfaction, Quality and Strategic Planning, RAE - Revista de Administração de Empresas, 40(1), 42-46.

Salkić, I. (2014). Impact of strategic planning on management of public organizations in Bosnia and Herzegovina. Interdisciplinary Description of Complex Systems: INDECS, 12(1), 61-77. https://doi.org/10.7906/indecs.12.1.4

Scholes, J., Regner, P., Johnson, G., Whittington, R., \& Angwin, D. (2011). Exploring strategy: text \& cases.

Service, N. S., \& Municipal, R. (2000). Strategic Management, Local Government Resource Handbook, PartVI-Section 6.1). Retrieved July 2, 2017, From; https://novascotia.ca/dma/publications/government-resource-handbook.asp

Shahin, A. (2006). SERVQUAL and model of service quality gaps: A framework for determining and prioritizing critical factors in delivering quality services. Service quality-An introduction, 117-131.

Shahin, A., \& Samea, M. (2010). Developing the models of service quality gaps: a critical discussion. Business Management and Strategy, 1(1), 1. https://doi.org/10.5296/bms.v1i1.395

Siam, A. (2010). Application of Strategic Planning and its Relationship with Performance of _Non-Governmental Organization in the Gaza Strip, Thesis of Science in Business Administration, Al-Azhar University- Gaza Strip-Palestine.

Tavakol, M., \& Dennick, R. (2011). Making sense of Cronbach's alpha. International journal of medical education, 2, 53. https://doi.org/10.5116/ijme.4dfb.8dfd

Uma, S., \& Roger, B. (2003). Research methods for business: A skill building approach. book.

Uncles, M. D., Dowling, G. R., \& Hammond, K. (2003). Customer loyalty and customer loyalty programs. Journal of Consumer Marketing, 20(4), 294-316. https://doi.org/10.1108/07363760310483676

Vagias, W. M. (2006). Likert-type scale response anchors. clemson international institute for tourism. \& Research Development, Department of Parks, Recreation and Tourism Management, Clemson University.

Wheelen, T. L., \& Hunger, J. D. (2011). Concepts in strategic management and business policy. Pearson Education India.

Yarimoglu, E. K. (2014). A review on dimensions of service quality models. Journal of Marketing Management, 2(2), 79-93.

\section{Copyrights}

Copyright for this article is retained by the author(s), with first publication rights granted to the journal.

This is an open-access article distributed under the terms and conditions of the Creative Commons Attribution license (http://creativecommons.org/licenses/by/4.0/). 